\title{
PHARMACEUTICAL SUPPORT IN LIVER TRANSPLANTATION AT A REFERENCE CENTER IN RIO GRANDE DO SUL
}

\author{
Assistência farmacêutica no transplante de fígado em um centro de referência no \\ Rio Grande do Sul
}

\author{
Mariana de Andrade Pranke, Maria Lúcia Zanotelli, Alfeu Fleck Jr., Ajácio Brandão, Cláudio Marroni, Guido Cantisani
}

\begin{abstract}
The introduction of the everolimus as immunosuppressant in the liver transplantation has been shown to be safe and effective in the prophylaxis and preservation of the renal function. Prospective follow-up and chart analysis of liver transplant patients treated with everolimus was performed. Purpose: To highlight the importance of the pharmacist in transplantation centers. Method: Along the study, 93 patients were included, being 72 under active treatment. The successful treatment depends on the multidisciplinary follow-up, and it is extremely important the involvement of the patient, making him to become positive and an active part of the treatment. Results: The most frequent problems were: patients cutting the everolimus tablet, late $S L$ after dose adjustment, lack of adhesion to the collection, and serum level collection out of time. Discussion: Upon the introduction of new drugs, it is required to observe possible adverse events further to ensure that the patient correctly follows the treatment. Conclusion: The presence of the pharmacist in the transplantation center allows the patient to get a reference to clarify doubts on the proper use of immunosuppressant.
\end{abstract}

Keywords: Pharmaceutical Care, Everolimus, Immunosuppressant.

Instituições:

Setor de Transplantes, Hosp.Geral de Fortaleza, Fortaleza/CE

\section{Correspondência:}

Mariana de Andrade Pranke

Rua Coronel Lucas de Oliveira,1618/304 - CEP 90460-000

Porto Alegre/RS - Brasil.

Tel.: (51) 98350-0082

E-mail: maripranke@gmail.com
Transplanted patients use several medications, demanding a specialized follow up, so that there is correct adherence to the treatment. The updating of the immunosuppressive protocol upon introducing everolimus (EVR), an inhibitor of the mammalian target of rapamycin (mTOR) complex in liver transplantation (LTx), has been shown to be safe and effective in the prophylaxis of rejection and preservation of renal function..$^{1-2}$

\section{PURPOSE}

The purpose of this study is to demonstrate the importance of the pharmacist in the multidisciplinary care, especially when new drugs are introduced. 


\section{METHODS}

Prospective follow-up and chart analysis of livertransplanted patients in the presence of hepatocellular carcinoma and/or acute renal injury treated with EVR between June 2016 and March 2017. Patients were instructed after receiving post-LTx informative material on the immunosuppressant (IMS) medication pointing out the importance of the correct continuity of the treatment and collecting serum level (SL). In periods of EVR shortage in the public network, patients were advised on the best dose adjustment, based on SL.

\section{RESULTS}

During the period of the study, 93 patients were included:, being 72 were under active treatment. From them, 69 (95.8\%) patients were under pharmaceutical follow-up, and $23(31.9 \%)$ were advised during hospitalization. During follow-up, $12(16.7 \%)$ patients had difficulty to make the adjustment for SL of EVR. Those patients had a special approach, so that to identify the possible interferers, such as administration at the wrong time, wrong dose, and SL collection out of time. A frequently encountered problem was the shortage of medication in the public network. Along the period, $8(11.1 \%)$ patients were followed up for guidance and dose adjustment upon the EVR shortage. In addition, the most frequent problems were: patients cutting the EVR tablet, late SL after dose adjustment, lack of the adhesion to the collection, and SL collection out of time.

\section{DISCUSSION}

The results show that the detailed analysis of the medical records and routine examinations allow the identification of poor adherence to the treatment and preventing adverse events. Upon the introduction of new drugs, it is required to observe possible adverse events further to ensure that the patient correctly follows the treatment.

\section{CONCLUSION}

The success of the therapy is a multifactorial condition, and the multidisciplinary team has an extremely important role for the patient to become involved with his condition and an active part in the treatment. Thus, the presence of the pharmacist in the transplantation center allows the patient to get a reference to clarify doubts on the proper use of IMS, justifying the importance of the pharmaceutical care in the routine care of transplanted patients.

\section{RESUMO}

A introdução do everolimo no tratamento imunossupressor no transplante hepático mostrou-se seguro e eficaz na profilaxia de rejeição e preservação da função renal. Foi realizado estudo prospectivo com análise de prontuários de pacientes com transplante hepático tratados com everolimo. Objetivo: Ressaltar a importância do farmacêutico no centro de transplantes. Método: Durante o estudo, foram incluídos 93 pacientes, sendo que 72 estavam com tratamento ativo. O sucesso do tratamento depende de acompanhamento multidisciplinar e é de extrema importância no envolvimento do paciente, fazendo que ele seja proativo ao longo do tratamento. Resultados: Durante o período do estudo, foram incluídos 93 pacientes. Os problemas mais frequentes foram: pacientes que cortaram o comprimido de everolimo, coleta de nível sérico tardia após ajuste da dose, falta de adesão à coleta e coleta fora do tempo. Conclusão: Após a introdução de novos medicamentos, é necessário observar possíveis eventos adversos para garantir que o paciente siga corretamente o tratamento. A presença do farmacêutico no centro de transplantes permite ao paciente obter uma referência para esclarecer dúvidas sobre o uso adequado dos imunossupressores.

Descritores: Atenção Farmacêutica, Everolimo, Imunossupressão. 


\section{REFERÊNCIAS}

1. Tonelli M, Wiebe N, Knoll G, Bello A, Browne S, Jadhav D, et al. Systematic review: kidney transplantation compared with dialysis in clinically relevant outcomes. Am J Transplant. 2011;11(10):2093-109.
2. Harada KM, Mandia-Sampaio EL, de Sandes-Freitas TV, Felipe CR, Park SI, Pinheiro-Machado PG, et al. Risk factors associated with graft loss and patient survival after kidney transplantation. Transplant Proc. 2009;41(9):3667-70. 